\title{
Fungal prosthetic mitral valve endocarditis caused by Scopulariopsis species: Case report and review of the literature
}

\author{
Alice May B. Isidro, MS, ${ }^{a}$ Valerianna Amorosa, MD, ${ }^{b}$ Gary A. Stopyra, MD, ${ }^{c}$ Harold L. Rutenberg, MD, ${ }^{d}$ \\ William H. Pentz, MD, ${ }^{d}$ and Charles R. Bridges, MD, ScD, ${ }^{a}$ Philadelphia, $\mathrm{Pa}$
}

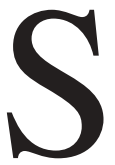

copulariopsis species is a keratinolytic mold with a propensity to cause onychomycosis and rarely to cause deep tissue infection. Scopulariopsis brevicaulis is the most common Scopulariopsis species seen clinically. We review 3 cases of Scopulariopsis species-induced endocarditis in the literature and present a fourth case of Scopulariopsis speciesinduced prosthetic valve endocarditis.

\section{Clinical Summary}

A 67-year-old woman with a past medical history significant for rheumatic fever, gout, pulmonary hypertension, atrial fibrillation, congestive heart failure, and 3 prior valve operations presented with fever and right leg pain. One year before presentation she underwent replacement of her aortic and mitral valves with a 19-mm Carpentier-Edwards Magna pericardial valve and a 25-mm Carpentier-Edwards pericardial valve (Baxter Healthcare Corp, Edwards Lifesciences, Irvine, Calif), respectively. Her social history was significant for pet finches. Her temperature was $101^{\circ} \mathrm{F}$, she had a systolic murmur at the left sternal border, and her right foot was cold with diminished pulses. She had no evidence of onychomycosis or peripheral emboli. Abdominal computed tomography demonstrated a nonocclusive clot in the right ileac artery. Hematologic parameters and chemistries were normal. Blood cultures, including fungal isolator blood cultures incubated over 4 weeks, were negative. After the patient's left leg became cold and pulseless, she urgently underwent thromboendarterectomy of an acutely occluded femoral artery. Pathology from the embolectomized specimen demonstrated septated hyphal elements. Subsequently on day 5, fungal cultures grew a mold morphologically identified as a Scopulariopsis species (Figure 1). She underwent a transesophageal echocardiogram revealing a larger than $12-\mathrm{mm}$ vegetation on the mitral valve with moderate mitral regurgitation. Confirmatory identification and susceptibility testing

From the Department of Surgery, ${ }^{\text {a }}$ the University of Pennsylvania Health System, Pennsylvania Hospital, Philadelphia, Pa; the Department of Medicine, ${ }^{\mathrm{b}}$ Division of Infectious Diseases, University of Pennsylvania Health System, Philadelphia, Pa; and the Department of Pathology ${ }^{\mathrm{c}}$ and Division of Cardiology, ${ }^{\mathrm{d}}$ Pennsylvania Hospital, ${ }^{\mathrm{c}}$ Philadelphia, Pa.

Received for publication Nov 17, 2005; revisions received Dec 22, 2005; accepted for publication Dec 30, 2005.

Address for reprints: Charles R. Bridges, MD, ScD, Department of Surgery, the University of Pennsylvania Health System, 4 Silverstein, Hospital of the University of Pennsylvania, Philadelphia, PA 19104 (E-mail: cbridges@ pahosp.com)

J Thorac Cardiovasc Surg 2006;131:1181-3

$0022-5223 / \$ 32.00$

Copyright () 2006 by The American Association for Thoracic Surgery doi:10.1016/j.jtcvs.2005.12.062

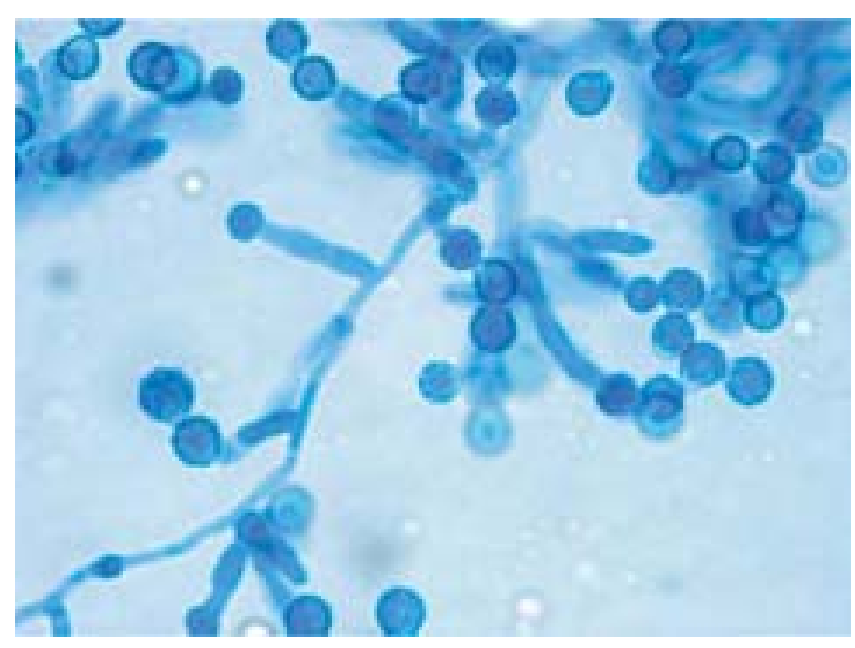

Figure 1. Scopulariopsis species isolated from the patient's thrombectomy. (Original magnification 1000x; lactophenol cotton blue stain.)

performed at Focus Diagnostics (Cyprus, Calif) identified the organism as $S$ brevicaulis and demonstrated mean inhibitory concentrations of $4 \mu \mathrm{g} / \mathrm{mL}$ to amphotericin B, $1 \mu \mathrm{g} / \mathrm{mL}$ to terbinafine, $8 \mu \mathrm{g} / \mathrm{mL}$ to voriconazole, and greater than $8 \mu \mathrm{g} / \mathrm{mL}$ to itraconazole. The patient underwent excision of the senescent infected mitral valve pericardial prosthesis, extensive debridement of the associated fungal vegetation, and a mitral valve replacement with a Carpentier-Edwards pericardial valve. She was treated preoperatively and postoperatively with amphotericin B and voriconazole. The amphotericin was continued for 3 weeks postoperatively, and the voriconazole was arbitrarily continued for 11 weeks until the patient could not tolerate it because of debilitating nausea. She had a complicated respiratory course postoperatively and was discharged to a rehabilitation facility. She was subsequently readmitted with dyspnea and died 5 months after initial presentation without signs of recurrent infection. Culture of her pet finch's feathers grew Aspergillus species and not Scopulariopsis species, despite the mold's propensity to grow in bird feathers.

\section{Discussion}

Fungi are responsible for less than $10 \%$ of cases of infective endocarditis. Although the majority of these are caused by Candida species, infections with opportunistic mold are seen in patients with previous valve operations. ${ }^{1}$

In the last 10 years, prosthetic valvular endocarditis caused by Scopulariopsis species has been reported in 3 cases in the literature (Table 1). ${ }^{2-4}$ Major emboli, a common presentation of fungal 
TABLE 1. Four cases of prosthetic valve endocarditis caused by Scopulariopsis species

\begin{tabular}{|c|c|c|c|c|c|}
\hline Case & $\begin{array}{l}\text { Presentation- } \\
\text { echocardiogram }\end{array}$ & Timing of presentation & Diagnostic study & Treatment & Outcome \\
\hline $\begin{array}{l}\text { Gentry and } \\
\text { coworkers, } 1995^{2}\end{array}$ & $\begin{array}{l}\text { Abdominal pain, } \\
\text { hematuria caused } \\
\text { by large renal } \\
\text { infarct; } \\
\text { pedunculated } \\
\text { vegetation on } \\
\text { echocardiogram }\end{array}$ & $\begin{array}{l}\text { Twelve months after } \\
\text { valvuloplasty with } \\
\text { Duran prosthetic } \\
\text { ring }\end{array}$ & $\begin{array}{l}\text { Valve culture } \\
\text { grew } S \\
\text { brevicaulis }\end{array}$ & $\begin{array}{l}\text { Surgical debridement } \\
\text { and new St Jude's } \\
\text { mitral prosthesis; } 66 \\
\text { days of amphoteri- } \\
\text { cin B and then } 90 \\
\text { days of itraconazole }\end{array}$ & $\begin{array}{l}\text { No recurrence at } \\
\text { follow-up }\end{array}$ \\
\hline $\begin{array}{l}\text { Migrino and } \\
\text { coworkers, } 1995^{3}\end{array}$ & $\begin{array}{l}\text { Chest pain; } \\
\text { echocardiogram } \\
\text { demonstrating } 3 \\
\text { cm of vegetation } \\
\text { on aortic } \\
\text { prosthesis; then } \\
\text { right leg } \\
\text { claudication with } \\
\text { embolism to } \\
\text { femoral artery }\end{array}$ & $\begin{array}{l}\text { Presented } 11 \\
\text { months after } \\
\text { Carpentier- } \\
\text { Edward aortic } \\
\text { valve replacement } \\
\text { for AS }\end{array}$ & $\begin{array}{l}\text { All blood cultures, } \\
\text { including fungal } \\
\text { isolator blood } \\
\text { cultures, were } \\
\text { negative; } \\
\text { cultures of the } \\
\text { embolus and } \\
\text { prosthesis grew } \\
S \text { brevicaulis }\end{array}$ & $\begin{array}{l}\text { Treated with } \\
\text { amphotericin B and } \\
\text { ketoconazole for } \\
\text { synergy; highly } \\
\text { resistant in vitro to } \\
\text { all agents }\end{array}$ & $\begin{array}{l}\text { Progressive infection } \\
\text { leading to death } \\
\text { despite } 2 \text { valve } \\
\text { operations and } \\
\text { antifungal therapy }\end{array}$ \\
\hline $\begin{array}{c}\text { Chen-Scarabelli and } \\
\text { Scarabelli } 2003^{4}\end{array}$ & $\begin{array}{l}\text { Fever, purple } \\
\text { fingers; } \\
\text { echocardiogram } \\
\text { with vegetations } \\
\text { on ventricular } \\
\text { side of MV and } \\
\text { linear atrial } \\
\text { densities }\end{array}$ & $\begin{array}{l}\text { Five months after } \\
\text { her third mitral } \\
\text { valve replacement }\end{array}$ & $\begin{array}{l}\text { All blood cultures } \\
\text { were negative; } \\
\text { valve culture } \\
\text { grew } \\
\text { Scopulariopsis } \\
\text { species }\end{array}$ & $\begin{array}{l}\text { Bioprosthetic valve } \\
\text { replacement of } \\
\text { mechanical valve, } \\
\text { treatment with } \\
\text { caspofungin }\end{array}$ & $\begin{array}{l}\text { Alive at hospital } \\
\text { discharge }\end{array}$ \\
\hline Current case & $\begin{array}{l}\text { Cold leg, femoral } \\
\text { arterial septic } \\
\text { emboli; } \\
\text { echocardiogram } \\
\text { with } 12 \text { mm of } \\
\text { mitral vegetation }\end{array}$ & $\begin{array}{l}\text { One year (see } \\
\text { above for details) }\end{array}$ & $\begin{array}{l}\text { Blood cultures } \\
\text { and fungal } \\
\text { isolator blood } \\
\text { cultures were } \\
\text { negative; } \\
\text { culture of } \\
\text { embolus grew } \\
S \text { brevicaulis }\end{array}$ & $\begin{array}{l}\text { Treated preoperatively } \\
\text { with amphotericin B } \\
\text { and voriconazole; } \\
\text { bioprosthetic valve } \\
\text { replacement; } \\
\text { treated } \\
\text { postoperatively with } \\
4 \text { weeks of } \\
\text { amphotericin and } 11 \\
\text { weeks of } \\
\text { voriconazole }\end{array}$ & $\begin{array}{l}\text { Alive at hospital } \\
\text { discharge; } \\
\text { ultimately expired } \\
\text { from pulmonary } \\
\text { complications } \\
\text { without } \\
\text { recurrence }\end{array}$ \\
\hline
\end{tabular}

$A S$, Aortic stenosis; $M V$, mitral valve.

endocarditis, ${ }^{1}$ occurred in 3 of the 4 reported cases, including our case. Blood cultures did not grow in any of the cases, and the diagnoses were based on fungal cultures of embolectomy tissue and prosthetic heart valves. In the cases in which susceptibility patterns were reported, the organism demonstrated significant in vitro resistance to multiple antifungal agents, corroborating with other reports noting high-level resistance in clinical isolates of $S$ brevicaulis. ${ }^{5}$ Fungal valvular vegetations generally require surgical intervention for treatment because a long-term cure for fungal prosthetic endocarditis is unlikely. Subsequent antimicrobial therapy is typically continued for long durations. Although clinical correlation with in vitro susceptibility data is not fully established for Scopulariopsis species, the high level of in vitro resistance demonstrated for Scopulariopsis species to multiple antifungal agents, ${ }^{5}$ taken together with several reports of emergency and progressive infection on broad antifungal therapy, suggests that successful treatment without surgical debridement might be even more unlikely for Scopulariopsis species than for other more treatment-responsive fungi. ${ }^{2-4}$ The appropriate duration of antifungal therapy after surgical intervention is unclear, although it is reasonable to continue antifungal agents for several weeks to months through endothelialization of a prosthetic valve. When Scopulariopsis species is identified in a clinical specimen, before susceptibility results are known, initial empiric use of intravenous amphotericin B alone or in combination with voriconazole or itraconazole is reasonable. Additional experience is needed to optimize antifungal selection in this setting, particularly as relates to combination antifungal therapy and the role of newer azoles, such as posaconazole; the echinocandins, such as caspofungin; or the allylamine terbinafine in synergy. Given the intrinsic resistance 
demonstrated by Scopulariopsis species in vitro, early surgical debridement is the mainstay of therapy for Scopulariopsis speciesinduced endocarditis and should be strongly considered when Scopulariopsis species infection is diagnosed.

\section{References}

1. Ellis ME, Al-abdely H, Sandridge A, Greer W, Ventura W. Fungal endocarditis: evidence in the world literature, 1965-1955. Clin Infect Dis. 2001;32:50-62.
2. Gentry LO, Nasser MM, Kielhofner M. Scopulariopsis endocarditis associated with Duran ring valvuloplasty. Tex Heart Inst J. 1995;22:81-5.

3. Migrino RQ, Hall QS, Longworth DL. Deep tissue infections caused by Scopulariopsis brevicaulis: report of a case of prosthetic valve endocarditis and review. Clin Infect Dis. 1995;21:672-4.

4. Chen-Scarabelli C, Scarabelli TM. Fungal endocarditis due to Scopulariopsis. Ann Intern Med. 2003;139:w-77.

5. Cuenca-Estrella M, Gomez-Lopez A, Mellado E, Buitrago M, Monzon A, Rodriguez-Tudela J. Scopulariopsis brevicaulis, a fungal pathogen resistant to broad-spectrum antifungal agents. Antimicrob Agents Chemother. 2003;47:2339-41.

\title{
Erosion of a retroesophageal subclavian artery by an esophageal prosthesis
}

\author{
Frédéric Vanden Eynden, $\mathrm{MD},{ }^{a}$ Jacques Devière, $\mathrm{MD}, \mathrm{PhD},{ }^{\mathrm{b}}$ Marc Laureys, $\mathrm{MD},{ }^{\mathrm{c}}$ and
} Didier de Cannière, $\mathrm{MD}, \mathrm{PhD}^{\mathrm{a}}$ Brussels, Belgium

$$
\begin{aligned}
& \text { Supplemental material is avail- } \\
& \text { able online }
\end{aligned}
$$

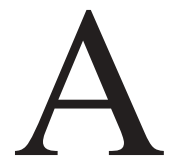

rterioesophageal fistula is a rare cause of upper digestive hemorrhage. It usually presents with a fatal outcome. It may happen in the course of esophageal or thoracic disease, or in the setting of foreign body ingestion, and involves the thoracic aorta or the subclavian artery.

Arterioesophageal fistula can also occur in the presence of a retroesophageal subclavian artery (RESCA), also known as arteria lusoria. It is usually asymptomatic but may cause dysphagia ( $d y s$ phagia lusoria) and may demonstrate symptomatic atherosclerotic and aneurysmal degeneration. However, spontaneous fistulization in the esophagus is not described. It has mostly been associated with prolonged nasogastric tube presence. The present report describes the first case of arterioesophageal fistula with a RESCA caused by an esophageal prosthesis and discusses treatment based on a review of the literature.

From the Service de Chirurgie Cardiaque, ${ }^{a}$ Service de gastro-entérologie, ${ }^{b}$ and Service de radiologie interventionelle, ${ }^{\mathrm{C}}$ Hôpital Erasme, Université Libre de Bruxelles, Brussels, Belgium

Received for publication Nov 14, 2005; accepted for publication Dec 1, 2005.

Address for reprints: Pr. Didier de Cannière, Service de Chirurgie cardiaque, Hôpital Erasme, Brussels University Medical School, 808 route de Lennick, 1070 Anderlecht, Belgium (E-mail: didier.decanniere@ulb.ac.be).

J Thorac Cardiovasc Surg 2006;131:1183-4

$0022-5223 / \$ 32.00$

Copyright $\odot 2006$ by The American Association for Thoracic Surgery doi:10.1016/j.jtcvs.2005.12.026

\section{Clinical Summary}

Fourteen months before the actual admission, a 9-year-old girl with Down syndrome was admitted for caustic ingestion. She presented with severe ulceration from the middle esophagus down to the stomach. The acute episode was treated conservatively. Nonetheless, dysphagia rapidly developed in the patient. Two months after the accident, an esophagoscopy disclosed active stenotic esophagitis of the last third of the esophagus. Iterative pneumatic dilatations were performed, which were discontinued because of esophageal fissuration and mediastinitis. A 14-mm Polyflex stent was inserted that rapidly migrated into the stomach; it was extracted and replaced by a $16-\mathrm{mm}$ stent.

In June 2005, the patient was admitted for hematemesis and melena. Emergency esophagoscopy showed blood oozing around the prosthesis. The endoscopic procedure was interrupted, and the child was brought to the catheterization laboratory where the prosthesis could be mobilized under angiographic control. When the prosthesis was pushed toward the stomach, a major hemorrhage occurred and a big aortic branch was identified as the source of bleeding. First it was regarded as a major bronchial artery. The prosthesis was pulled back to enable partial control of the bleeding, and coil embolization was performed in the so-called bronchial artery. This maneuver did not control the hemorrhage, and a RESCA was identified as the source of bleeding (Figure 1). RESCA embolization was attempted unsuccessfully, despite satisfactory angiographic images (Figure 2), and the patient presented sustained bleeding with hemorrhagic shock and cardiac arrest. After successful reanimation the patient underwent emergency surgery consisting of ostial RESCA ligature while the endoesophageal prosthesis was left in place. An 8-mm polytetrafluoroethylene (Gore-Tex, Flagstaff, Ariz) prosthetic bypass was constructed between the lateral aspect of the ascending aorta and the axillary artery. The patient had a prolonged intensive care unit stay (23 days) but fully recovered and was discharged without aftereffects. Although the first esophagoscopic control showed embolized coils visible through the ulcerated esophageal mucosa (Figure E1), the lesions finally healed. 